\title{
CZECH WINE CONSUMERS: MATURING WITH AGE?
}

\author{
John R. Anchor, Tereza Lacinová
}

\section{Introduction}

Wine is a complex beverage which varies in taste, in categories and in quality measures. These factors may influence consumers' preferences. The most important factor is probably taste, although consumers usually cannot taste wine before a purchase and so other factors are important in the decision making process [5]. The motivation for wine drinking is important as well. Knowledge of situations connected with wine consumption, of what role wine plays in consumers' lifestyles and of other important motivations helps to understand the purchase decision.

There have been number of studies of the behaviour of wine drinkers [7], [8], [9], [10], [11], [32], [33], [34], [41]. The markets of Australasia, the USA and Europe have been studied in relation to consumer behaviour and the segmentation of wine consumers [7], [8], [9], [10], [11], [32], [33], [34], [41]. It has been noted that consumption patterns in the food and beverage sector are influenced by cultural factors [47]. However there has been no dedicated study in the Czech Republic. It would be interesting to see, therefore, whether or not consumer behaviour is different in this postcommunist transition economy [2], [49].

The history of Czech wine growing goes back to the $3^{\text {rd }}$ century, and although the $20^{\text {th }}$ century saw a decline in consumption and in the number of wineries, the last twenty years have seen a rebirth of the Czech wine industry [17]. The consumption of wine accounted for $11 \%$ of the volume of alcoholic beverages consumed in the Czech Republic in 2010, while the average consumption was 19.4 litres of wine per person per year [13]. These numbers are growing slowly, possibly because of growing knowledge about wine and a decrease in prices caused by international competition [16]. The Czech Republic is a net importer of wine, importing more than half of its consumption, although the consumption of local wines has grown with time. The main competitor to wine in the Czech Republic, as an alcoholic drink, is beer. Beer is very popular in the Czech Republic, and its consumption accounted for $85 \%$ of the volume of alcoholic beverages consumed in the Czech Republic in 2010, although the consumption has been decreasing slowly in since 2005 [13], [30].

Although there have been major developments in the techniques for growing wine in the past few decades, there has been no major developments in the marketing of it [16], [41]. The wine industry seems to be struggling to find a way to become more market oriented and remains production-oriented. The wine market has long traditions; therefore it cannot be described as an innovative sector and it is agriculturally-based [9]. The problem lies in the mass-marketing strategy adopted by wine producers because wine is more part of a lifestyle than just an everyday product [34].

The main objective of this study is to identify the most important motivations for Czech consumers to drink wine and the factors involved in wine purchase since no study of this kind of Czech consumers has been undertaken. As wine consumption is growing in importance in the Czech Republic, especially in the south-eastern region of Moravia, knowledge of consumers is pivotal. The main focus of this study is to find out if there are any differences between genders and age groups, as basic segmentation factors, in relation to the consumption of wine in the Czech Republic.

\section{Literature Review}

The purchase process for wine is complex, since it has many dimensions which can influence decision making. There are not only thousands of brands and products, but numerous wine 
styles, grape varieties, vintages, labels and wine regions. In addition, price plays a very important role in the decision making process [40], [29], [44], [45].

Wine is the "combination of a noble grape, the creative artistry of the winemaker and the tradition of the package" [51]. The core benefit expresses the reason why consumers may prefer wine to other alcoholic beverages and in this paper this is referred to as "the motivation to drink wine". These motivations are made tangible by using consumers' senses of sight, touch and smell, while presenting the advantages of the product, by for example using a unique design, controlling the quality of packaging or/and displaying the provenance, brand, grape variety and other factors on the bottle or in the information material.

Intangible factors, such as price, outlets where the wines are sold, or image, are used to gain competitive advantage using differentiation [51].

The importance of each of these factors has been explored in several studies of the Australian and New Zealand wine markets [12], [40], [55], [9], as well as the US wine market [41], [26]. In Europe, there have been consumer-oriented segmentation studies of the Swiss and Irish wine markets [7], [21].

The main approach to studying wine buying behaviour seems to be market segmentation. The authors of the various studies have tried to create segments of wine consumers based on different factors - for example lifestyle which influence wine consumption [8], [29], [9]. Lifestyle is a set of values and is defined as: "patterns in which people live and spend time and money" [6]. All of the studies concerning lifestyle factors have proved the importance of them, as wine is a cultural beverage with a long history. There are social and cultural factors associated with drinking wine, which differentiate this product from many other alcoholic beverages with a shorter history.

Consumers can be segmented according to their involvement in purchase and consumption, which is generally characterized as the level of interest in an object or activity. It can be divided into product involvement, brand decision involvement and purchasing involvement [35]. A product involved consumer pays a lot of attention to buying a certain product; for example wine. When consumers are highly involved in selecting a certain brand, the behaviour is called 'brand purchasing involvement' and a consumer who is interested in purchase itself is 'purchasing involved' [7]. Consumers are often 'product involved' in the wine market, as it can be complicated to choose wine because of the existence of a large number of types and brands; and it is often important for consumers to choose the "right" wine, especially when buying it as a gift. Given the large number of brands, types and flavours, brand purchasing involvement might not be so common when buying wine [15], [35].

Purchasing involvement is an important factor in the wine market. Many wine consumers actually enjoy the journey of choosing and buying wine and the experience gained from it, as well as the product itself [41], [24]. The level at which involvement influences the purchase decision has been studied extensively [35], [33], [27].

One of the most important types of segmentation of wine consumers is that which is based on the benefits from and the motives for purchase [7]. Dubow's segmentation study pays attention to the internal motives for the consumption of wine such as: "I like the taste" or "to be stylish", while dividing consumers into five groups. To the first of them belong consumers who drank wine for the wine itself (because they like it). The second group drank wine to feel good and enjoy leisure time. The third group drank wine because they "wanted something light, natural and healthy" [7], [18]. To the fourth group belonged consumers who drank wine to be more friendly and sociable and consumers in the fifth group were characterized by the need to be stylish and distinctive.

The identification of consumers' segments is a very important thing for the wine market, as it allows the marketer to focus the campaign on certain segments which cause the campaign to have a greater effect than a non-specified and non-targeted global campaign. Although segmentation seems to be very important, researchers seem to forget another very important field of wine consumer behaviour - the search for the determinants of wine consumption [8]. Looking for these determinants can show the marketer which factor in his campaign is the most important. He can also focus his campaign on the groups with the biggest consumption.

Previous studies have often focused on finding out demographic facts about consumers - for example the fact that consumption grows 
with age [12]. However lifestyle determinants have been studied less extensively [8].

Considering all these factors and putting them together to reach the final decision might incorporate a certain amount of risk and make a consumer feel insecure, uncomfortable and sceptical and may aggravate his decision by adding pressure to the situation [40], [37]. The perceived amount of risk grows with the level of formality of the situation the wine is bought for. As wine usually cannot be tasted before purchase, the consumer tends to lower the risk by focusing on the elements which he can be most sure about. The risk-reduction strategies can be summarized as follows: the consumer can choose one of the brands he knows already and can be sure of its quality (1); he can decide according to the recommendations of family or friends (2); he can buy what the salesperson recommends to him (3); he can use his own knowledge of wine (4); he can consider price as a value growing with quality (5); or he can decide according to the packaging and label (6) [3].

\subsection{Demographic Determinants of Wine Consumption}

The demographic determinants of wine purchase are the key factors of segmentation, as they lead to the most straightforward separation of groups which have a high probability of having a lot in common.

\subsubsection{Gender}

Gender may impact upon wine consumption in a number of ways. According to the Wine Market Council [54], for instance, $77 \%$ of women in the USA regularly buy wine for their households. Research in Australia found that men had slightly greater consumption than women [10]. Research in the US wine market showed that $56 \%$ of all wine consumers were women [54] which might reflect the fact that wine is "generally perceived as a "feminine" beverage" [50]. Australian studies prove that the strongest gender differences are in the volume of wine consumed, grape variety and wine style [10], [11]. According to a UK study, women have strong preferences for white wine since only $34 \%$ of them prefer red wine compared to $48 \%$ who prefer white wine [12]. These observations are supported by Australian results, which found that men are much less likely than women to drink white and sparkling wines [25]. Although there are clear gender differences in terms of colour related preferences in wine consumption, Robinson [46] argues that women (and men] are too heterogeneous a group to make generalizations about in this context.

\subsubsection{Age}

According to Lockshin et al. [35], wine consumption tends to grow with age. This can be explained by the fact that wine is a beverage with a complex taste and it takes some time for consumers to get used to it and to start recognizing the various flavours and styles. When a consumer gets used to the taste and becomes more aware of what to expect from certain kinds of wine, he can be more relaxed and buying is not so time consuming for him anymore, which can boost consumption [35].

Bruwer, Saliba and Miller [12] found out that another significant difference between age groups is the extent to which they pay attention to salespeople and waiters in the restaurant. Younger generations require a greater level of advice about wine purchase than older generations, which can be explained by the fact that knowledge about wine is gained with experience.

Wine marketers have recently taken age differences into consideration [12] while researching the differences in the volume of consumption between generations $X$ and $Y$ and their consuming situations [20]. According to Bruwer, Li and Reid [9], marketers should focus on consumers before the age of twenty in order to teach them to drink wine in the years when they form their consumption habits.

Hall, Binney and O'Mahony [23] conducted research on Australian wine consumers, focusing on some of their motivations to drink wine and the factors which are important in purchasing wine. They divided consumers into three age groups, while looking at the differences in their behaviour. They found that the factor 'Wine and Food Matching' (consisting of wine region, grape variety and matching wine with food) was least important to the youngest age group, while other factors like 'Price and Value' (price, discounts, value and value for money) and 'Product Attribute' (taste, type of wine) did not show significant differences between the age groups. Younger age groups showed higher preferences for sampling and seeking advice, while older consumers cared more about the quality of wine than the younger ones. 


\subsubsection{Knowledge}

Johnson and Bastian [28] conducted a study looking at the impact of the level of expertise (knowledge) in the wine field on consumption and spending on wine. Two tests were run a sensory and a knowledge test, which found that there was a positive correlation between the level of expertise and the amount of wine consumed. Greater expertise was correlated also with higher spending on wine.

A question of causality arises - it is not clear if consumers drink more wine because they know more about it, or if they know about it more because they drink more of it [8].

Knowledge is usually related to age as well, as complexity of wine knowledge causes learning to take some time. As wine knowledge is usually gained as a leisure activity ("hobby"), a positive correlation between age and knowledge can be assumed.

\subsection{Lifestyle Determinants of Wine Purchase}

Lifestyle determinants describe consumers' backgrounds and their motivations for drinking wine [48]. Research on the Swiss wine market showed that the most important motivations for drinking wine were social motivations drinking with friends, to be sociable and socially accepted, to be distinctive, respected or to show a mature personality, in order to celebrate something or as a family tradition. However, the most important motivation was liking the taste, while not liking the taste was the most important reason why consumers did not drink wine [3].

A desire for a healthy lifestyle is another, but quite complicated, motivation. MartinezCarrasco et al. [36], in a study of the Spanish wine market, found that health reasons for consuming wine were negatively correlated with the amount of wine consumed. Zanten [55] researched the US wine market and discovered that after finding out more about the positive impact of drinking wine, consumption increased, but only for a limited time. This means that the impact of health does not have a long-term influence on wine consumption.

\subsection{Wine Characteristics Influencing Wine Purchase}

The wine characteristics influencing the purchase of wine can be divided into four groups - intrinsic, extrinsic, in-store factors and situational [41], [9]. Consumers with a lower level of expertise may rely more on extrinsic factors, in comparison with more experienced consumers, who have knowledge about intrinsic factors and can use them in the decision process [34]. However, the extrinsic cues may be more important than the intrinsic ones, regardless of expertise, because of wine being consumed "primarily for the experience with little functional utility" [41].

The decision can change in a case when the consumer has already tasted the specific wine before [3], [32] or if it was recommended to him by friends or family [38]. The choice can be affected as well by the award of medals or prizes to a wine brand [32].

\subsubsection{Intrinsic Factors}

Intrinsic factors are factors associated with the wine itself, such as colour, taste and quality. Although taste is shown in many studies to be the most important reason for wine consumption [15], [7], it is hard for consumers to decide according to it, because in the typical buying situation they cannot taste the wine prior to purchase. The same problem arises with the evaluation of quality, as only the most experienced consumer can be sure of his decision. Colour is the only intrinsic cue, according to which the consumer is able to decide easily and it is one of the first factors which consumers may evaluate prior to purchase.

As the intrinsic factors are hard to evaluate for the majority of consumers, other factors need to be taken into consideration and it is usually the extrinsic set of factors which decide the purchase.

\subsubsection{Extrinsic Factors}

The most important extrinsic factor for wine purchase is price [42]. In situations when consumers cannot decide a purchase by considering only intrinsic factors, they often use price because of its expected positive correlation with quality.

The front and back labels of wine bottles are designed to provide the consumer with exactly the type of information he seeks and needs for a decision and to suit consumers' tastes and style. The packaging is very important for both functional and emotional reasons - it must provide the information and functions needed and must be attractive at the same time [3]. Packaging is 
one of the cues which consumers use to evaluate the quality of a wine. It is interesting that there is a general preference for natural cork-closed bottles, while plastic corks are accepted neutrally and wines closed by screw caps are considered to be of lower quality [3].

The information which can be found on labels includes the brand name, vintage, grape variety, description of taste, wine style, food fitting reccomendations or production procedures [31], [53]. The back label helps consumers to decide, since the majority of them are not able to match the wine with its label description [14].

\subsubsection{Geographical Context}

The geographical origin of a wine is a key extrinsic factor in fluencing its consumption. The third most important extrinsic factor in Australia is the region of origin and the country of origin is one of the most important extrinsic factors in Europe [5].

\subsubsection{Situational Context}

The choices which consumers make do not rely only on the product itself, but they are affected also by factors in the shopping environment; for example by shelf position, advertising banners, information on the shelves, lighting, crowding and music [4], [3], [27], [32].

The purchase situation is important as well, consisting of the actual place of purchase (restaurant, supermarket, specialized shop) and the situation the wine is being bought for (just for relaxing, as a gift, for a collection) [19], [3], [41]. The factors which consumers decide on may vary in different situations [9], [1].

\section{Methodology}

In order to investigate which are the important influences on wine purchase, as well as the motivation for drinking wine, in the Czech Republic, a questionnaire survey was conducted. The questionnaire adopted a majority of the questions from Brunner and Siegrist's [7] study of Swiss wine consumers. As the main factors influencing wine consumption have been researched qualitatively in previous studies (mostly outside Europe), a quantitative method was chosen. An online questionnaire containing 39 questions was run for two weeks using e-mail and social networks.

The first part of the questionnaire contained general questions about wine consumption, asking consumers, for example, how much wine they drink per week, where they buy it, or about their preference for Czech or imported wines. The second part asked about their motivation to drink wine, the third about factors influencing them when they buy wine and the fourth part contained demographic questions. One of the general questions concerned subjective knowledge (consumers' perception of their knowledge about wine); while objective knowledge was not included in the study. In two weeks, 268 respondents opened the questionnaire page, and the final sample size was $n=237$, after the elimination of incomplete questionnaires.

The sample is not fully random since the respondents were contacted via e-mail and social networks. A generalization for the whole of the Czech Republic cannot be made since $72 \%$ of respondents stated that they were from the South Moravia Region (Jihomoravský kraj), one of 14 Czech regions. Only people who drink wine at least once a year were asked to complete the questionnaire.

$60 \%$ of respondents were women. If age is taken into consideration, women are in the majority only in the youngest age group (1825 ), while the older groups have slightly more males. This result can be explained by the authors' perception of the younger generation in the Czech Republic that wine is seen as a predominantly female beverage, or the fact that among young males, beer is the drink of choice.

To measure the agreement of consumers with various statements concerning the motivation for and factors associated with wine drinking, scale questions were used, while the possible answers were from 1 to 6 , where 1 stands for "I strongly agree" and 6 for "I strongly disagree."

Three age groups were defined to describe the youngest generation of wine drinkers (aged 18-25), the middle generation (aged 26-45) and the oldest generation (aged 46 and more). The results from the scale questions were compared between these age groups in order to identify differences in behaviour.

Cronbach's alpha was used to test the level of reliability of the results. Spearman's rank correlation coefficient was used to compare the results of questions about motivation and the factors influencing wine purchase between age groups. A comparison of the results by gender was tested by chi-square. 


\section{Results and Discussion}

Two sets of findings result from the primary research - an analysis of wine consumer motivation and the factors influencing the purchase of wine; and a comparison and difference analysis for age groups and gender segments. The age and gender layout of the sample can be seen in Figure $1.60 \%$ of the sample was female, $45 \%$ were less than 25 years of age with $21 \%$ being over 46 .

\section{Fig. 1: Breakdown of sample by age and gender}

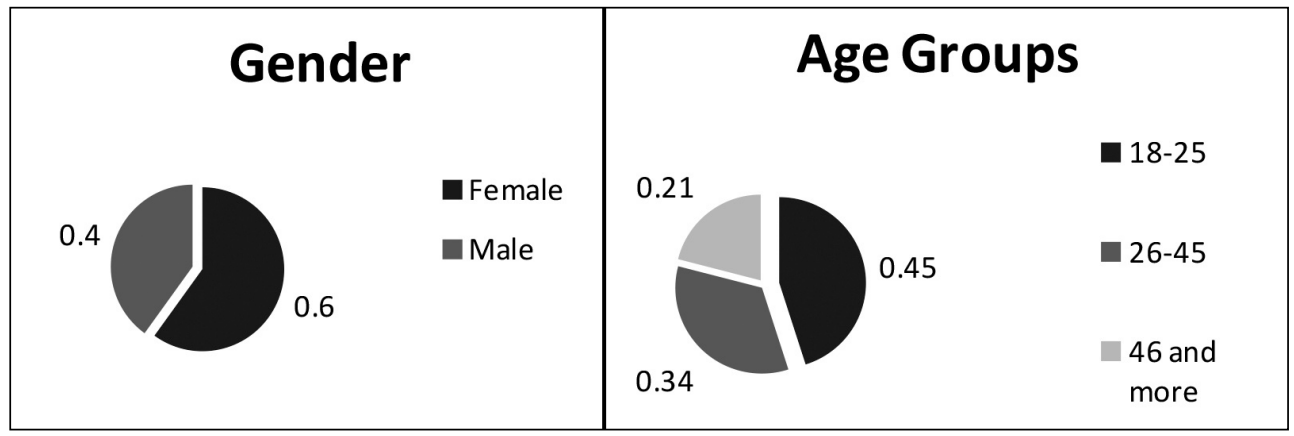

Source: Questionnaire results

Tables 1 to 3 show the percentage wine drinking history of consumers, their preferred packaging and place of purchase. More than $50 \%$ of respondents had been drinking wine for 10 years or less which might indicate that there is an extensive pool of inexperienced wine drinkers.

In the case of the preferred places for wine purchase, "in a specialized shop" was most common, while "from a local wine producer" and "in a supermarket" were close behind. The most preferred packaging was glass bottles (56\%) and wine drafted from barrels to plastic bottles (37\%).
$83 \%$ of respondents consumed five or fewer glasses of wine per week with $39 \%$ of the sample consuming one or none. $70 \%$ of the sample had a stated preference for Czech wines.

Weekly consumption and preferences concerning wine origin can be seen in Tables $4 \& 5$.

Consumption is significantly correlated with age at the 0.01 level and there is greater consumption of wine with increasing age. This result is in line with earlier research [35], [7]. Knowledge was significantly positively

\section{Tab. 1: Longevity of wine drinking}

\begin{tabular}{l|c} 
How long have you been a wine drinker? \\
\hline Less than a year & $6.9 \%$ \\
\hline $1-10$ years & $50.7 \%$ \\
\hline $11-20$ years & $16.7 \%$ \\
\hline $21-30$ years & $12.0 \%$ \\
\hline More than 30 years & $13.7 \%$ \\
\hline
\end{tabular}


Tab. 2: Wine packaging preferences

Which of these do you prefer (buy most often)?

\begin{tabular}{l|c}
\hline Drafted wine & $37.4 \%$ \\
\hline Bottled wine (glass) & $56.1 \%$ \\
\hline Bottled wine (plastic) & $2.6 \%$ \\
\hline Wine in carton boxes & $0.9 \%$ \\
\hline Other & $3.0 \%$ \\
\hline
\end{tabular}

\section{Tab. 3: Wine purchasing location}

Where do you usually buy wines? (multi-choice question)

\begin{tabular}{l|c}
\hline In a specialised shop & $33.7 \%$ \\
\hline In a local supermarket & $23.5 \%$ \\
\hline In a corner-shop & $6.0 \%$ \\
\hline From a local wine producer & $24.7 \%$ \\
\hline Other & $7.0 \%$ \\
\hline
\end{tabular}

\section{Tab. 4: Weekly wine consumption}

How many glasses $(0.21)$ of wine do you drink per week?

\begin{tabular}{l|c}
\hline $0-1$ & 93 \\
\hline $2-5$ & 104 \\
\hline $6-10$ & 28 \\
\hline $11-15$ & 7 \\
\hline 16 and more & 6 \\
\hline
\end{tabular}

\section{Tab. 5: Provenance preference}

\section{Do you prefer Czech or foreign wine?}

\begin{tabular}{l|c}
\hline I always prefer Czech wines & 78 \\
\hline I usually prefer Czech wines & 89 \\
\hline Without a preference & 56 \\
\hline I usually prefer foreign wines & 13 \\
\hline I always prefer foreign wines & 1 \\
\hline
\end{tabular}


correlated with consumption at the 0.01 level as well. Earlier studies have identified this feature [8], [41]. Growing consumption with age and knowledge is considered to be interrelated, since with growing age and knowledge the consumer is more able to savour complex flavours and to understand better the factors which differentiate wines.

\subsection{Motivations to Drink Wine}

The strongest motivation for drinking wine found in this study was taste, which is in line with the results of earlier studies [12], [52], [5].

The second biggest motivation to drink wine was "to celebrate something", which is understandable as wine, especially sparkling wine, which is known as sec or demi sec, is consumed often as a festive beverage in the Czech Republic.

Wine drinking in Switzerland is associated with celebrations and festive occasions [7]. This study had similar results for the third most important motivation found in this study - the belief that wine belongs with a nice meal.

Factors such as "I drink wine to be distinctive" or "to be socially accepted" were the most negatively evaluated questions. Cronbach's alpha was above 0.7 in all cases, which indicates an acceptable level of reliability. The results for the questions concerning motivation to drink wine can be seen in Table 6 .

Differences between age groups were tested by Spearman's rank correlation coefficient, while differences between genders were tested by chisquare.

\section{Tab. 6: Motivations to drink wine - Means, Cronbach's $\alpha$ and Spearman's coefficient}

\begin{tabular}{l|c|c|c}
\hline I drink wine..... & Mean & Cronbach's $\alpha$ & $\begin{array}{c}\text { Spearman's } \\
\text { coefficent }\end{array}$ \\
\hline Because I love the taste & 1.7722 & 0.767 & -.004 \\
\hline To celebrate something & 2.1308 & 0.765 & -.005 \\
\hline Because a glass of wine belongs to a nice meal & 3.0886 & 0.763 & -.186 \\
\hline Because I consider wine healthy & 3.3966 & 0.762 & -.188 \\
\hline Because it is a tradition in my family & 4.2194 & 0.754 & -.061 \\
\hline To be sociable & 4.5738 & 0.752 & -.144 \\
\hline Because drinking wine testifies to a mature & 5.0127 & 0.749 & -.013 \\
\hline personality & 5.1561 & 0.752 & -.140 \\
\hline To be respected & 5.2278 & 0.748 & -.032 \\
\hline To be socially accepted & 5.4388 & 0.752 & -.009 \\
\hline To be distinctive & & & \\
\hline
\end{tabular}

Note: ${ }^{*}$ Correlation is signifiant at the 0.05 level (2-tailed). ${ }^{* *}$ Correlation is significant at the 0.01 level (2-tailed). The questions are ordered according to the mean (that is according to the importance of the motivation of the respondents) from the most important to the least important.

There were no significant differences between genders; however, the biggest difference was found in the case of the answer "to be distinctive".

In the case of motivations to drink wine, two variables were found to be correlated with age at the 0.05 level, while two more variables were correlated with age at the 0.01 level. The strongest correlation with age was the motivation "because I consider wine healthy," where the importance of the factor grew with age. The second strongest correlation was with "because a glass of wine belongs to a nice meal", while its importance grew with age as well. Other correlations were between age and the variables "to be respected" and "to be sociable", while the importance of these factors decreased with age. 


\subsection{Factors Important in Wine Purchase}

The most important choice factor was the grape variety. A similar result has been found for the main segment of US wine consumers [32], [7], [8]. The information on the label is a key factor since it contains a lot of information, e.g. the provenance, which was the second most important factor in choosing wine. This result may be connected to a very strong inclination to buy Czech wines since more than $70 \%$ of respondents answered that they more commonly buy Czech wines rather than imports. Cronbach's alpha was around 0.760.77 in all cases, which indicated an acceptable level of reliability. The results of the questions concerning the factors which influence wine purchase can be seen in Table 7.

\section{Tab. 7: Factors influencing wine purchase - Means, Cronbach's $\alpha$ and Spearman's}

\begin{tabular}{l|c|c|c} 
When buying wine, I pay attention to ...... & Mean & Cronbach's $\alpha$ & $\begin{array}{c}\text { Spearman's } \\
\text { coefficent }\end{array}$ \\
\hline Grape variety & 1.9662 & .765 & -.053 \\
\hline All the infomation on the label & 2.0633 & .770 & -.192 \\
\hline Producer/Brand & 2.2363 & .768 & -.136 \\
\hline Provenance & 2.3207 & .763 & -.141 \\
\hline The best possible price/quality ratio & 2.3671 & .768 & .019 \\
\hline Recommendations of friends and acquaintances & 2.6034 & .768 & .039 \\
\hline Wine from local producers & 2.8312 & .770 & -.065 \\
\hline Vintage & 3.0549 & .764 & -.191 \\
\hline A well-established producer & 3.3080 & .769 & -.079 \\
\hline Recommendations of salesperson & 3.8903 & .768 & .182 \\
\hline The design of the bottle and the label & 4.1392 & .760 & .254 \\
\hline Bargains and special offers & 4.1477 & .759 & .094 \\
\hline I nearly always choose one of the lowest priced & 4.9409 & .766 & .220 \\
\hline wines & 5.0591 & .762 & .070
\end{tabular}

Note: ${ }^{*}$ Correlation is signifiant at the 0.05 level (2-tailed). ${ }^{\star *}$ Correlation is significant at the 0.01 level (2-tailed). The questions are ordered according to the mean (that is according to the importance of the motivation of the respondents) from the most important to the least important.

Source: own

Several strong correlations were found between age groups and the factors influencing wine purchase. The strongest correlation was with "the design of the bottle and the label" where the youngest consumers reported that they were influenced by these factors much more than older ones. Other factors with a significant correlation, such as the label, vintage, provenance and brand/producer, increase in importance with age. This can be explained by the fact that making decisions according to these factors might be too complicated for inexperienced consumers, but with age, consumers usually gain knowledge and are more able to evaluate them.
In the case of "I nearly always choose one of the lowest priced wines" and "recommendations of salesperson", the trend is diverse - their importance decreases with age, which can be explained by the lower disposable income of the youngest consumers and by their greater uncertainty when buying wine (and so the need to ask for advice).

There are major differences between generations in the Czech Republic in the importance of the factors which they pay attention to when buying wine. Older consumers seem to be more interested in the factors which require a certain level of knowledge to be 
understood, as there are many combinations of label information with vintage and countries of origin vineries from thousands of producers. As younger consumers generally have a lower level of knowledge about wine, it is hard for them to decide according to those factors and they look at other, less complex clues, such as design of the bottle, or they seek advice from the salesperson. The greater importance of choosing the lowest priced wines for younger generations is understandable, given that disposable income usually increases with age.

Therefore it seems that younger consumers drink wine more for social reasons, while older consumers are more likely to consume alone and at home and to focus on the internal aspect of wine - it being healthy and a part of a meal.

\section{Conclusions}

The aim of this study was to explore the differences in wine buying behaviour between genders and age groups, as well as their motivations for drinking wine, in the Czech Republic. The other factors researched were knowledge about wine and its relationship to consumption and to find out which factors and motivations are the most important for Czech consumers.

A review of the literature identified some of the likely main factors in purchasing decisions. These were included in a questionnaire survey which was conducted in the Czech Republic. There were 237 usable responses, mainly from the South Moravia Region (Jihomoravský kraj).

The taste of wine and the availability of a special, celebratory, occasion were the strongest influences upon purchase decisions. Gender differences were not statistically significant discriminators of motivation. It was found that the younger age groups were motivated to a greater extent by social aspects, while those of more mature years showed a tendency to drink wine because it is healthy and with a meal.

The most important factor in choosing wine was the grape variety. Major differences were found between age groups, as older consumers focused significantly on more complex factors such as label, vintage, provenance, and the identity of the producer. Younger consumers reported a stronger interest in looking at design and seeking advice. This could be explained by the low level of expertise of young consumers, who tend to make the decision on the basis of less complicated factors, which can be due to the fact that experience is usually gained with age. Another explanation could be that younger consumers may differ in their level of involvement in the purchase, as they might be interested only in the drinking of wine and not in the purchase process. That could be explained by the different lifestyles of the younger generation. Therefore, younger consumers could be looking for ways to make the decision as easy as possible and therefore they choose factors which take little time to evaluate.

Consumption grew with both age and knowledge. Men reported higher levels of consumption than women. Consumers showed a clear preference for Czech wines, rather than imports. Such a strong inclination for own wine seems to be less common in other countries and could be used in the marketing of Czech wines. The reasons for this inclination could be the focus of future studies, particularly in Central Europe. It may be that the Czech Republic has entered a phase of its post communist development which leads wine consumers to want to explore home grown products more than imports from established western producers.

The study was limited mainly by the sample, as it was not random. The only generalization possible can be drawn for the region of origin of the majority of respondents, although the sample was quite big. Future research could test these results in other wine consuming regions of the Czech Republic.

This study has important implications for marketers, as age is shown to be an important segmentation factor in the Czech wine market. Wine marketing campaigns should focus on different ways of targeting different age groups. Older consumers are more sophisticated in their purchasing decisions; however there may be the potential to wean younger consumers from beer and other products via a targeted marketing campaign.

\section{References}

[1] AGNOLI, L., BEGALLI, D. and CAPITELLO, R. Generation Y's perception of wine and consumption situations in a traditional wineproducing region. International Journal of Wine Business Research. 2011, Vol. 23, Iss. 2, pp.176-192. ISSN 1751-1062. doi:http://dx.doi. org/10.1108/175110611111430257.

[2] ANCHOR, J. R., KOUŘILOVÁ, T. Consumer Perceptions of Tesco Own Brands: the Czech 
Republic and the United Kingdom. E+M Ekonomie a Management. 2008, Vol. 11, Iss. 4, pp. 119-131. ISSN 1212-3609.

[3] ATKIN, T., NOWAK, L. and GARCIA, R. Women wine consumers: information search and retailing implications. International Journal of Wine Business Research. 2007, Vol. 19, Iss. 4, pp. 327-339. ISSN 1751-1062. doi:http:// dx.doi.org/10.1108/17511060710837454.

[4] BACKSTROM, K. and JOHANSSON, U. Creating and consuming experiences in retail store environments: comparing retailer and consumer perspectives. Journal of Retailing and Consumer Services. 2006, Vol. 13, Iss. 6, pp. 417-430. ISSN 0969-6989. doi:http://dx.doi. org/10.1016/j.jretconser.2006.02.005.

[5] BATT, P. J. and DEAN, A. Factors influencing consumers' decision. Australian and New Zealand Wine Industry Journal. 2000, Vol. 15, Iss. 4, pp. 34-41.

[6] BLACKWELL, R., MINIARD, P. and ENGEL, J. Consumer Behavior. $10^{\text {th }}$ ed. Mason: Thomson Higher Education, 2006. ISBN 0324271972.

[7] BRUNNER, T. A. and SIEGRIST, M. A consumer-oriented segmentation study in the Swiss wine market. British Food Journal. 2011, Vol. 113, Iss.3,pp.353-373.ISSN0007-070X.doi:http:// dx.doi.org/10.1108/00070701111116437.

[8] BRUNNER, T. A. and SIEGRIST, M. Lifestyle determinants of wine consumption and spending on wine. International Journal of Wine Business Research. 2011, Vol. 23, Iss. 3, pp. 210-220. ISSN 1751-1062. doi:http://dx.doi. org/10.1108/17511061111163041.

[9] BRUWER, J., LI, E. and REID, M. Segmentation of the Australian Wine Market Using a Wine-Related Lifestyle Approach. Journal of Wine Research. 2002, Vol. 13, Iss. 3, pp. 217-242. ISSN 1469-9672. doi:http://dx.doi. org/10.1080/0957126022000046510.

[10] BRUWER, J. and JOHNSON, T. The Drivers of On-premise Beverage Selection in Australia, research report, Australian. Adelaide: Wine and Brandy Corporation, 2005. ISBN 0959318011.

[11] BRUWER, J. and LI, E. Wine-related lifestyle (WRL) segmentation: demographic and behavioural factors. Journal of Wine Research. 2007, Vol. 18, Iss. 1, pp. 19-34. ISSN 1469-9672. doi:http://dx.doi.org/10.1080/09571260701526865. [12] BRUWER, J., SALIBA, A. and MILLER, B. Consumer behaviour and sensory preference differences: implications for wine product marketing. Journal of Consumer Marketing. 2011, Vol. 28, Iss. 1, pp. 5-18. ISSN 0736-3761. doi:http://dx.doi.org/10.1108/07363761111101903. [13] ČESKÝ STATISTICKÝ ÚŘAD. Česká republika od roku 1989 v číslech [online]. Prague: Czech Statistical Office, 2012 [cit. 2014-02-21]. http://www.czso.cz/csu/redakce. nsf/i/cr_od_roku_1989.

[14] CHARTERS, S., LOCKSHIN, L. and UNWIN, T. Consumer responses to wine back labels. Australian and New Zealand Wine Industry Journal. 2000, Vol. 15, Iss. 3, pp. 94-101. doi:http://dx.doi. org/10.1080/09571269908718177.

[15] CHARTERS, S. Wine and Society. Oxford: Elsevier Butterworth-Heinemann, 2006. ISBN 0750666358.

[16] CHLÁDKOVÁ, H. Rozhodovani spotrebitelu pri nakupu vina. Decision making in wine purchase. International Scientific Days 17-18, 2006. Nitra: Faculty of Economic and Management SAU in Nitra, May 2006.

[17] CHLÁDKOVÁ, H.,TOMŠíK, P. and GURSKÁ, $\mathrm{S}$. The development of main factors of the wine demand. Agricultural Economics. 2009, Vol. 55, No. 7, pp 321-326. ISSN 0139-570X.

[18] DUBOW, J. Occasion-based vs user-based benefit segmentation: a case study. Journal of Advertising Research. 1992, Vol. 32, Iss. 2, pp. 11-18. ISSN 0021-8499.

[19] FENNELL, G. Consumers' perceptions of the product-use situation. Journal of Marketing. 1978, Vol. 4, Iss. 2, pp. 38-47. ISSN 0022-2429. [20] FOUNTAIN, J. and LAMB, CH. Generation $Y$ as young wine consumers in New Zealand: how do they differ from Generation $X$ ? International Journal of Wine Business Research. 2011, Vol. 23, Iss. 2, pp.107124. ISSN 1751-1062. doi:http://dx.doi. org/10.1108/17511061111142981.

[21] GERAGHTY, S. and TORRES, A. M. The Irish wine market: a market segmentation study. International Journal of Wine Business Research. 2009, Vol. 21, Iss. 2, pp. 143154. ISSN 1751-1062. doi:http://dx.doi. org/10.1108/17511060910967980.

[22] HALL, J., WINCHESTER, M. Focus on your customer through segmentation. Australian and New Zealand Wine Industry Journal. 2000, Vol. 15, Iss. 2, pp. 93-96.

[23] HALL, J., BINNEY, W., O'MAHONY, G. B. Age Related Motivational Segmentation of Wine Consumption in a Hospitality Setting. International Journal of Wine Marketing. 1993, Vol. 16, Iss. 3, pp. 29-43. ISSN 0954-7541. doi:http://dx.doi.org/10.1108/eb008777. 
[24] HIRSCHMAN, E. C., HOLBROOK, M. B. Hedonic consumption: emerging concepts, methods and propositions. Journal of Marketing. 1982, Vol. 46, Iss. 3, pp. 92-101. ISSN 00222429. doi:http://dx.doi.org/10.2307/1251707.

[25] HOFFMAN, C. A. When consumers buy wine, what factors decide the final purchase? Australian and New Zealand Wine Industry Journal. 2004, Vol. 19, Iss. 2, pp. 82-91.

[26] HUSSAIN, M., CHOLETTE, S.andCASTALDI, R. Determinants of wine consumption of US consumers: an econometric analysis. International Journal of Wine Business Research. 2007, Vol. 19, Iss. 1, pp. 49-62. ISSN 1751-1062. doi:http:// dx.doi.org/10.1108/17511060710740343.

[27]JAEGER, S.R., DANAHER, P.J.andBRODIE, R. J. Wine purchase decisions and consumption behaviours: insights from a probability sample drawn in Auckland, New Zealand. Food Quality and Preference. 2009, Vol. 20, Iss. 4, pp. 312-319. ISSN 0950-3293. doi:http://dx.doi.org/10.1016/j. foodqual.2009.02.003.

[28] JOHNSON, T. and BASTIAN, S. A preliminary study of the relationship between Australian wine consumers' wine expertise and their wine purchasing and consumption behavior. Australian Journal of Grape and Wine Research. 2007, Vol. 13, Iss. 3, pp. 186-197. ISSN 1755-0238. doi:http://dx.doi. org/10.1111/j.1755-0238.2007.tb00249.x.

[29] JOHNSON, T. and BRUWER, J. Generic consumer risk-reduction strategies (RRS) in wine-related lifestyle segments of the Australian wine market. International Journal of Wine Marketing. 2004, Vol. 16, Iss. 1, pp. 5-35. ISSN 0954-7541. doi:http://dx.doi.org/10.1108/ eb008764.

[30] KOZÁK, V. Analysis of Reasons for Beer Consumption Drop in the Czech Republic. E+M Ekonomie a Management. 2013, Vol. 16, Iss. 3, pp. 130-138. ISSN 1212-3609.

[31] LING, B. H. and LOCKSHIN, L. Components of wine prices for Australian wine: How winery reputation, wine quality, region, vintage, and winery size contribute to the price of varietal wines. Australasian Marketing Journal. 2003, Vol. 11, Iss. 3, pp. 19-32. ISSN 1441-3582. doi:http:// dx.doi.org/10.1016/S1441-3582(03)70132-3.

[32] LOCKSHIN, L. and COHEN, E. Using product and retail choice attributes for crossnational segmentation. European Journal of Marketing. 2011, Vol. 45, Iss. 7, pp.12361252. ISSN 0309-0566. doi:http://dx.doi. org/10.1108/03090561111137697.
[33] LOCKSHIN, L. and HALSTEAD, L. A comparison of Australian and Canadian wine buyers using discrete choice analysis. In: Proceedings of the 2nd international wine marketing symposium. 8-9 July, 2005. Sonoma County (USA): Rohnert Park, 2005. http:// academyofwinebusiness.com/up-content/ upload/2010/05Canada_Australia.pdf.

[34] LOCKSHIN, L. S. and RHODUS, W. T. The effect of price and oak flavor on perceived wine quality. International Journal of Wine Marketing. 1993, Vol. 5, Iss. 2, pp. 13-25. ISSN 0954-7541. doi:http://dx.doi.org/10.1108/eb008614.

[35] LOCKSHIN, L., SPAWTON, A. and MACINTOSH, G. Using product, brand and purchasing involvement for retail segmentation. Journal of Retailing and Consumer Services. 1997, Vol. 4, Iss. 3, pp. 171-183. ISSN 09696989. doi:http://dx.doi.org/10.1016/S09696989(96)00048-3.

[36]MARTINEZ-CARRASCO,L.,BRUGAROLAS, M. and MARTINEZ-POVEDA, A. Quality wines and wines protected by a designation of origin: identifying their consumption determinants. Journal of Wine Research. 2005, Vol. 16, Iss. 3, pp. 213-232. ISSN 1469-9672. doi:http://dx.doi. org/10.1080/09571260600556690.

[37] MCCARTHY, M. and HENSON, S. Perceived risk and risk reduction strategies in the choice of beef by Irish consumers. Food Quality and Preference. 2005, Vol. 16, Iss. 5, pp. 435-445. ISSN 0950-3293. doi:http://dx.doi. org/10.1016/j.foodqual.2004.08.003.

[38] MCCUTCHEON, E., BRUWER, J. and LI, E. Region of origin and its importance among choice factors in the wine-buying decision making of consumers. International Journal of Wine Business Research. 2009, Vol. 21, Iss. 3, pp. 212-234. ISSN 1751-1062. doi:http://dx.doi. org/10.1108/17511060910985953.

[39] MINISTERSVO ZEMĚDĚLSTVÍ (Ministry of Agriculture). Situační a výhlednová zpráva : Víno a vinná réva. Těšnov: Ministerstvo zemědělství ČR, 2011.

[40] MUELLER, S., LOCKSHIN, L., SALTMAN, Y. and BLANFORD, J. Message on a bottle: The relative influence of wine back label information on wine choice. Food Quality and Preference. 2010, Vol. 21, Iss. 1, pp. 22-32. ISSN 0950-3293. doi:http://dx.doi.org/10.1016/j. foodqual.2009.07.004.

[41] NEELEY, C. R., MIN, K. S. and KENNETTHENSEL, P. A. Contingent consumer decision making in the wine industry: the role of 
hedonic orientation. Journal of Consumer Marketing. 2010, Vol. 27, Iss. 4, pp. 324335. ISSN 0736-3761. doi:http://dx.doi. org/10.1108/07363761011052369.

[42] OCZKOWSKI, E. Hedonic wine price functions and measurement error. Economic Record. 2001, Vol. 77, Iss. 239, pp. 374382. ISSN 1475-4932. doi:http://dx.doi.org/ 10.1111/1475-4932.00030.

[43] ORTH, U. Research Note: Targeting the un-experienced and the convenience shopper. International Journal of Wine Marketing. 2002, Vol. 14, Iss. 3, pp. 80-82. ISSN 0954-7541. doi:http://dx.doi.org/ 10.1108/eb008748.

[44] OVERBY, J. W., GARDIAL, S. F. and WOODRUFF, R. B. French versus America consumers' attachment of value to a product in a common consumption context: a cross national comparison. Journal of Academy of Marketing Science. 2004, Vol. 32, Iss. 4, pp. 437-460. ISSN 0092-0703. doi:http://dx.doi.org/ 10.1177/0092070304265697.

[45] RASMUSSEN, M. and LOCKSHIN, L. Wine choice behaviour: the effect of regional branding. International Journal of Wine Marketing. 1999, Vol. 11, Iss. 1, pp. 36-46. ISSN 0954-7541. doi:http://dx.doi.org/ 10.1108/eb008689.

[46] ROBINSON, J. A woman's place is in the cellar. San Francisco Chronicle [online]. San Francisco: SFGate, 2004-07-08 [cit. 201402-21]. Available from: http://www.sfgate. com/wine/article/A-woman-s-place-is-in-thecellar-2743526.php.

[47] SANTOS, C. R., et al. Consumption Culture in Europe:Literature Review. IGI Global, 2013. ISBN 978-1-4666-2857-1.

[48] SIMOVÁ, J. Conceptual Models of Customer Value: Implications for Clothing Retailing. $E+M$ Ekonomie a Management. 2009, Vol. 12, Iss. 1, pp. 88-97. ISSN 1212-3609.
[49] SIMOVÁ, J. Internationalization in the Process of the Czech Retail Development. E+M Ekonomie a Management. 2010, Vol. 13, Iss. 2, pp. 78-91. ISSN 1212-3609.

[50] SPAWTON, A. L. Marketing planning for wine. International Journal of Wine Marketing. 1990, Vol. 2, Iss. 2, pp. 19-31. ISSN 0954-7541. doi:http://dx.doi.org/10.1108/EUM0000000000617. [51] SPAWTON, T. Wine and the marketing mix. European Journal of Marketing. 1991, Vol. 25, Iss. 3, pp. 19-31. ISSN 0304-0566. doi:http:// dx.doi.org/ 10.1108/eb008580.

[52] THACH, E. C. and OLSEN, J. E. Market segment analysis to target young adult wine drinkers. Agribusiness. 2006, Vol. 22, Iss. 3, pp. 307-322. ISSN 1520-6297. doi:http://dx.doi. org/10.1002/agr.20088.

[53] THOMAS, A. Elements influencing wine purchasing: a New Zealand view. International Journal of Wine Marketing. 2000, Vol. 12, Iss. 2, pp. 47-62. ISSN 0954-7541. doi:http://dx.doi. org/10.1108/eb008709.

[54] WINE MARKET COUNCIL. The US Wine Market - Consumer Trends and Analysis 2009. Wine New York: Market Council, 2009. ISSN 0954-7541.

[55] ZANTEN, R. Drink Choice: Factors Influencing the Intention to Drink Wine. International Journal of Wine Marketing. 2005, Vol. 17, Iss. 2, pp. 49-61. ISSN 0954-7541. doi:http://dx.doi.org/10.1108/eb008788.

prof. John R. Anchor BSc, PhD University of Huddersfield Business School j.r.anchor@hud.ac.uk

Tereza Lacinová BA (Hons) Masaryk University

Faculty of Economics and Administration lacitez@gmail.com 


\section{Abstract}

\section{CZECH WINE CONSUMERS: MATURING WITH AGE?}

\section{John R. Anchor, Tereza Lacinová}

The purpose of this study is to identify the most important motivations for drinking wine and the factors influencing wine purchase in the Czech Republic and to ascertain if there are significant differences between genders and age groups. An online survey was conducted, using e-mail and social networks, of wine consumers in one of the 14 regions of the Czech Republic. This resulted in a sample of $n=237$. Spearman's correlation test was conducted to find correlations between wine consumption and age and the chi-square test for differences between genders. Four motivations were found to be significantly correlated with age - to be sociable, to be respected, because wine is considered healthy and because it belongs with a nice meal, as well as seven factors affecting wine purchase - label, provenance, brand/producer, vintage, design of the bottle, recommendations of salesperson and a preference for the lowest priced wines. As the majority of respondents came from one of the 14 Czech regions, generalizations for the whole Czech Republic cannot be made. It is recommended that future work should include more complex segmentation. This paper contributes to the literature by exploring the Czech wine market, where very little research has been conducted so far, as well as by exploring the influence of age on the motivation for wine consumption.

Key Words: Wine consumption, consumer behaviour, Czech Republic.

JEL Classiffication: M31.

DOI: 10.15240/tul/001/2015-1-013 